\title{
CORRIGENDUM
}

\section{Geometrical Figures and Generality in Ancient China and Beyond: Liu Hui and Zhao Shuang, Plato and Thabit ibn Qurra - CORRIGENDUM}

Chemla, Karine

doi:10.1017/S0269889705000396, Published by Cambridge University Press, March 2005

In the article (Chemla 2005), I provided a critical edition and translation of two texts. One text was a passage from The Gnomon of the Zhou, a book dealing with mathematical astronomy and probably completed in the form in which we know it around the beginning of the Common Era (translation on pp. 127-135). The other text was a passage from The Nine Chapters on Mathematical Procedures, a book that in my view took its final form in the first century C.E. (translation on pp. 146-151). I edited and translated both texts along with the third-century commentaries with which they were handed down through written transmission. In Chinese sources of the past, the main text was distinguished from its commentaries by the size of the characters: main texts in larger characters, commentaries in smaller characters. I reproduced this contrast by using the same feature, using larger characters for the main text and smaller characters for the commentaries. Unfortunately, the contrast was modified in the printed version of the Chinese texts in Appendixes A and B (pp. 164-166) of my critical edition. I give the two texts again, together with the footnotes and the references, this time displaying the characters with adequate contrast.

NB: The sign " $\circ$ " is used in Chinese transcriptions as the equivalent of a period, or full stop, in English; the inverted comma is used conventionally in Chinese transcriptions in connection with enumerations/lists.

\section{Appendix A}

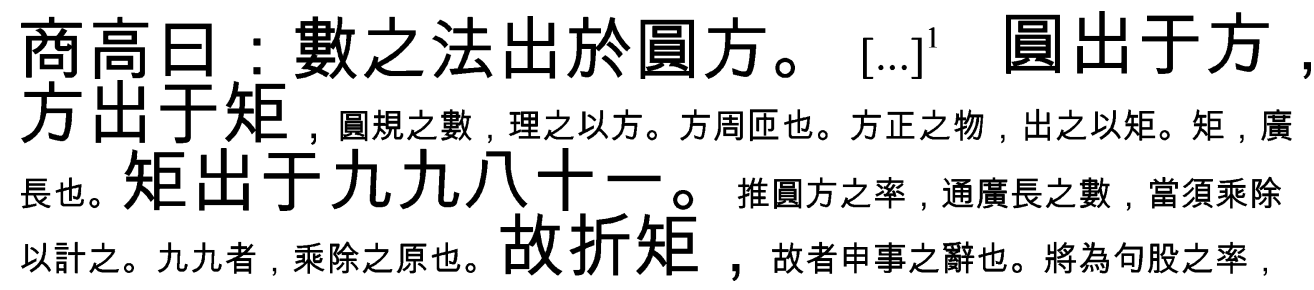

\footnotetext{
${ }^{1}$ I skip here a section of the commentary that is not essential in the context of this corrigendum.
} 
故曰“折矩”也。以為句廣三，應圓之周。横者，謂之廣，句亦廣。廣短 也。股修四, 應方之匝。從者, 謂之修, 股亦脩。脩, 長也。徑隅 五。自然相應之率。徑, 直; 隅, 角也。亦謂之弦。既方之, 外半 其一矩 ${ }^{2}$ 。句股之法, 先知二數然後推一。見句、股然後求弦, 先各自乘, 成 其實。實成勢化，爾乃變通。故日“既方”。其“外”3，或并句股之實以求弦，實妕乃 求句股之分并。實不正等，更相取與，互有所得。故日“半其一矩”。其術，句股各自 乘，三三如九，四四一十六，并為弦自乘之實二十五。減句於弦，為股之實一十六。 減股於弦, 為句之實九。環而共盤, 得成三、四、五。 ${ }^{2}$ This is the text as given by the three ancient editions on the basis of which The Gnomon of the Zhou can be
edited: the Southern Song edition, printed in 1213 by Bao Huanzhi 鮑澣之), the edition included in the Grand
encyclopedia of the reign period Yongle 永樂大典 (Li Jimin 李繼閔 1993a, 37, n. 1), and the edition printed by
Hu Zhenheng 胡震亨 in the Bice huihan 䟤冊彙函 collection in 1603 (Guo Shuchun 郭書春 and Liu Dun
劉鈍 2001, 68, n. 9, 10). The edition of the Collection Wuyingdian juzhen ban 武英殿聚珍版, edited by
Dai Zhen on the basis of the Hu Zhenheng edition, which he modified with reference to the Yongle dadian

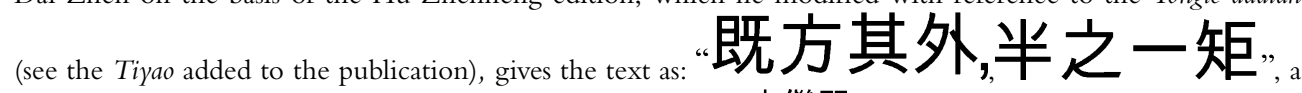
suggestion adopted by Qian Baocong in his edition. Li Jimin 李繼閔 1993a, 37, n. 1, considers the former to conform to the original. Guo Shuchun 郭書春 and Liu Dun 劉鈍 2001, 68, n. 9, also holds this view. However, these publications are punctuated in different ways. I follow here Li Jimin. Guo Shuchun 郭書春 and Liu Dun 劉鈍 2001,33, use the following punctuation: “既方多, 半其一矩”. ${ }^{3}$ This is the text as given by the Southern Song edition, the edition printed by Hu Zhenheng, as well as the edition of the Collection Wuyingdian juzhen ban. Li Jimin (1993a, 37, n. 1) suggests that Dai Zhen modified the text of The Gnomon of the Zhou to make it conform to the quotation made by the commentator here. Li Jimin solves the problem of the divergence between the main text and that quoted by the commentator, by punctuating the commentary in a new way. I follow him on this point too. Guo Shuchun and Liu Dun (2001, 68, n. 11) mention the divergence but keep the text as it is found in all the ancient editions in both places and adopt here the following punctuation (Guo Shuchun and Liu Dun 2001, 33): “故曰“既方其外”。或并...”. ${ }^{4}$ This is the text as given by the Southern Song edition, the edition included in the Grand encyclopedia of the reign period Yongle (Li Jimin 1993a, 37, n. 3) and the edition printed by Hu Zhenheng (Guo Shuchun and Liu Dun 2001, 68, n. 12). The edition of the Collection Wuyingdian juzhen ban adds one character: “以求弦實實之中乃求...”. Qian Baocong $(1963,16$, n. 2) adopts this suggestion. Li Jimin (1993a, 37, n. 3) considers that the ancient editions conform to the original text. Guo Shuchun and Liu Dun $(2001,68$, n. 12) also hold this view. However, these publications are punctuated in different ways. I follow here Li Jimin. Guo Shuchun and Liu Dun $(2001,33)$ use the following punctuation: “以求弦實, 之中乃求...”.

${ }^{5}$ This is the text as given by the Southern Song edition, the edition included in the Grand encyclopedia of the reign period Yongle and the edition printed by Hu Zhenheng (Guo Shuchun and Liu Dun 2001, 68, n. 10). The edition of the Collection Wuyingdian juzhen ban modifies it into: “半之一矩”, a point of view adopted by Qian Baocong 1963, 16, n. 3. Li Jimin (1993a, 37, n. 4) considers that the ancient editions conform to the original text. Guo Shuchun and Liu Dun $(2001,68$, n. 12) also hold this view. 
盤讀如盤桓之盤。言取其 ${ }^{6}$ 并減之積, 環、屈而共盤之謂 ${ }^{7}$ 。開方除之, 得 ${ }^{8}$ 其一面。故 曰“得成三、四、五”也。闹矢芫辰二十有五，是謂積 矩。兩矩者, 句、股各自乘之實。共長者, 并實之數。將以施於萬事, 而此先陳 其率也。故蚔之所以治天下者此數之所生也。

\section{Appendix B}

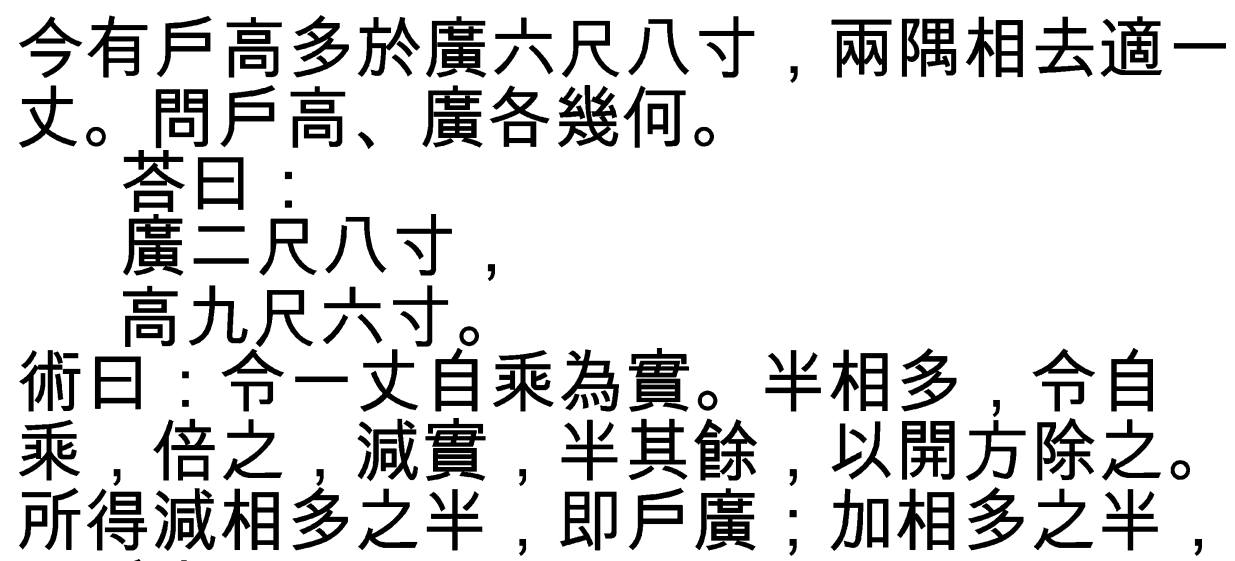

即戶高。令戶廣為句, 高為股, 兩隅相去一丈為弦, 高多於廣六尺八寸為句 股差。按圖為位, 弦幕適滿萬寸。倍之, 減句股差幕, 開方除之, 其所得即高廣并 數。以差減并而半之, 即戶廣; 加相多之數, 即戶高也。今此術先求其半。一丈自乘 為朱幕四、黃幕一。半差自乘, 又倍之, 為黃幕四分之二。減實, 半其餘, 有朱幕 二、黃幕四分之一。其於大方者四分之一。故開方除之, 得高廣并數半。半并數減差

\footnotetext{
${ }^{6}$ This is the text as given by Dai Zhen's edition of the Collection Wuyingdian juzhen ban and adopted by Qian Baocong 1963, 16, n. 4. The Southern Song edition and the edition printed by Hu Zhenheng have 之 for 其 (Guo Shuchun and Liu Dun 2001, 68, n. 13). Li Jimin (1993a, 37, n. 5), Guo Shuchun and Liu Dun (2001, 34), and Ch'en Liang-ts'o 陳良佐 (1993a, 7, n. 8) all adopt the latter in their editions. However, Guo Shuchun and Liu Dun 2001, 68, n. 12, give the former as a possible option. This is the option I consider best.

${ }^{7}$ This is the text given by the Southern Song edition and the edition printed by Hu Zhenheng. The latter character wei is not found in Dai Zhen's edition of the Collection Wuyingdian juzhen ban. Qian Baocong (1963, 17, n. 5) adopts the latter text in his edition. Li Jimin (1993a, 38, n. 1) and Guo Shuchun and Liu Dun (2001, 34) both adopt the former option in their edition, even though they do not agree on punctuation. Here, I follow the punctuation of Guo Shuchun and Liu Dun. Note that Guo Shuchun and Liu Dun $(2001,68$, n. 14) give the latter as a possible option.

${ }^{8}$ This character is omitted in the Southern Song edition (Li Jimin 1993a 38, n. 2) and in the edition printed by Hu Zhenheng. Dai Zhen restores it in his edition for the Collection Wuyingdian juzhen ban. Qian Baocong $(1963,17$, n. 6) adopts this emendation, an option also followed by Li Jimin 1993a, which I find preferable. Guo Shuchun and Liu Dun $(2001,69$, n. 15) consider both options possible and follow the Southern Song edition (Guo Shuchun and Liu Dun 2001, 34).
} 


\section{半, 得廣; 加, 得戶高。又, 按此圖幕，句股相并幕而加其差幕亦成9弦幕。為積， 蓋先見其弦，然後知其句與股。今適等，自乘，亦各為方，合為弦幕。令半相多而自 乘，倍之，又半并自乘，倍之，亦合為弦耑。而差數無者，此各自乘之，而與相乘 數，各為門實。及股長句短，同原而分流焉。}

\section{References}

Chemla, K. and Guo Shuchun. 2004. Les Neuf chapitres. Le Classique mathématique de la Chine ancienne et ses commentaires. Paris: Dunod.

Ch'en Liang-ts'so (Chen Liangzuo). 1993a. "Liu Hui gongu dingli shi tan (Tentative discussion on Liu Hui's proof of the theorem of base and height [Pythagorean theorem])." Shuxueshi yanjiu wenji (Collected research papers on the history of mathematics): 1-7 (in Chinese).

Guo Shuchun and Liu Dun. 1998. Suanjing shishu (Ten canons of mathematics). Shenyang: Liaoning jiaoyu chubanshe, 2 volumes.

Guo Shuchun and Liu Dun. 2001. Dian jiao Suanjing shishu (Punctuated edition of the Ten canons of mathematics). Taipei: Jiuzhang chubanshe. Reedition of the former.

Li Jimin. 1993a. "«Shang Gao dingli» bianzheng." Ziran Kexueshi Yanjiu (Research in the history of natural sciences) 12(1):29-41 (in Chinese).

Li Jimin 1993b. Jiuzhang suanshu jiaozheng (Critical edition of The Nine Chapters on Mathematical Procedures). 590 p. Xi'an: Shaanxi kexue jishu chubanshe (in Chinese).

Qian Baocong. 1963. Suanjing shi shu (Ten classics of mathematics). Beijing: Zhonghua shuju, 2 volumes.

\section{Reference}

Chemla, Karine. (2005). Geometrical Figures and Generality in Ancient China and Beyond: Liu Hui and Zhao Shuang, Plato and Thabit ibn Qurra. Science in Context 18(1), 123-166.

\footnotetext{
${ }^{9}$ Following an idea put forward by Li Jimin (1993b, 495-6) without however adopting his overall restoration of the sentence here, I suggest that the character “減” contained in the ancient editions here has been wrongly copied in place of the similar character “成”.
} 